\title{
The Russian forest sector: Sun and shadows ${ }^{1}$
}

\author{
by Charles A. Backman ${ }^{2}$
}

\section{Introduction}

The forest resources of Russia are enormous, accounting for one half of the global coniferous resource and one fifth of the non-tropical deciduous resource (Backman 1998b). This resource provided the raw material that supported the growth of a domestic forest industry, which in the years immediately preceding the demise of the former USSR (FSU) accounted for shares of global activity ranging from a high of $16 \%$ and $17 \%$ in lumber and industrial roundwood to $4 \%$ in paper and paperboard output (Backman 1998b). Even in the waning years of the Soviet era, the apparent untapped potential of the Russian forest resources amounted to almost triple the AAC of Canada. ${ }^{3}$

Since the late 1980s, with the collapse of the former FSU, activity has declined in Russia with that of the forest sector falling more precipitously. ${ }^{4}$ Not only has the surplus fibre supply magnified as a consequence, but the potential benefit of trading unused carbon credits has blossomed. ${ }^{5}$ Coupled with a large unused manufacturing capacity, pent-up domestic demand and potential markets in Europe and the Pacific Rim would suggest that the forest sector in Russia has a promising future. However, as will become evident below, there are a number of obstacles that need to be overcome before the forest sector can truly emerge from the shadows.

\section{Forest Resource and Annual Fibre Flow}

The Russian forest resource amounts to more than 80 billion cubic meters growing on almost 775 million hectares of stocked forest land, some three quarters of which consist of coniferous species-dominated forest (Backman 1998b). This

\footnotetext{
${ }^{1}$ An earlier version of this paper was presented at the University of Northern British Columbia (UNBC) (Prince George, BC, Canada) - Department of Natural Resources - Seminar Series, October 22, 1999

${ }^{2}$ Grande Prairie Regional College, Grande Prairie, Alberta T8V 4C4. E-mail: charles_backman@telus.net.

${ }^{3}$ If the growth potential of the Russian forests is taken to be 1137 million cubic meters (Backman 1998b); and the actual total harvest in 1989 is taken to be 437 million cubic meters (Backman 1999), then the apparent surplus to the then harvest amounted to 700 million cubic meters, a figure that needs to be factored down. The current allowable annual cut (AAC) in Canada amounts to just under 240 million cubic meters (http://nfdp.ccfm.org/)

${ }^{4}$ Goskomstat shows the index of industrial production declining between 1990 and 1997 by $51 \%$ (Goskomstat 1998). In contrast, the forest sector declined by $64 \%$ (Goskomstat 1998a).

5The agreement flowing from the Kyoto committed signatories of the protocol to a reduction of 1990 carbon emissions by 6 percent between 2008 and 2012. In meeting this target Canada would see a cost to the economy of between $\$ 8.4$ billion and $\$ 17$ billion. The cost of compliance for Canada can be greatly reduced if trading in unused allowable carbon discharge is allowed. Looking to Russia, the target against which compliance is measured is 1990, a year for which Russia was a part of the USSR. Output since then has fallen sharply; and as a consequence Russia has reduced its emission already by $28 \%$, far in excess of the $6 \%$ mandated by the protocol. The difference between what has been mandated and what has been achieved could be used to offset the reductions that Canada must make, thus having some economic value should the selling price be less than the cost of achieving the reductions in place. For further details see Duffy 1999.
}

resource is thought to support an annual growth potential in excess of one billion cubic meters. Since the demise of the FSU, the apparent surplus between what is harvested and this potential has grown from 700 million cubic meters to more than one billion cubic meters. $^{6}$

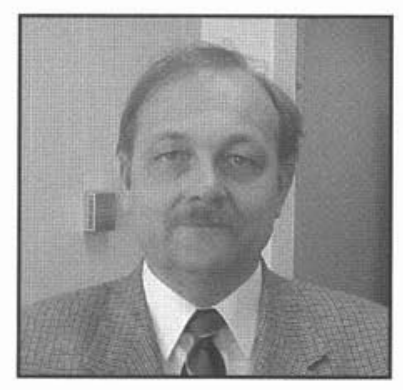

While these figure attract interest, not all is available to the wood processing industries. ${ }^{7}$ Part of the growth is linked to stands which are low site quality, supporting volume below what was considered economic in the FSU, part was linked to forests which have been dedicated to uses that preclude complete utilization by the forest processing industry, part lies in forest located far from transportation infrastructure accessible within two decades and expected to be in place within the next two decades under development priorities of the former regime. Leaving the share that is potentially available to the wood processing industry, a portion needs to be factored away because priorities of the former regime within two decades time horizon are no longer realistic. The remainder (289 million cubic meters annually) is believed to be the surplus, physically accessible wood fibre (independent of economic criteria) beyond current harvest levels.

Despite the net-downs, the indicated volume of surplus fibre is still a significant number. Looking deeper at its geographic, economic and species dimensions, though, reveals further shadows. One half of the unused resource is located in the eastern reaches of the country (West and East Siberia and the Far East), which is characterized by more extreme climatic conditions, isolation by distance from current markets and a significant share contributed by a deciduous resource. Not surprisingly, factoring in the economic criteria reduces the apparent surplus more sharply than in European Russia. While located in closer proximity to domestic demand and foreign markets, the available surplus in European Russia is characterized by a majority of deciduous species that pose a challenge to utilization due to a lower share of the tree having economic utility. ${ }^{8}$ Factoring in economic criteria reduces the surplus, though not to the same extent evident in the eastern portion of the country. Taking into account these other considerations reduces the overall surplus throughout Russia to slightly more than 100 million cubic meters.

\footnotetext{
${ }^{6}$ The harvest (vyvozka drevesiny) in 1998 according to Goskomstat amounted to 75 million cubic meters (Backman 1999). The actual harvest from all sources is believed to be in the vicinity of 128 million cubic meters (author's calculations). Subtracting 128 million from 1137 million yields just over one billion cubic meters.

${ }^{7}$ Backman 1998b provides a description of the different categories of "withdrawals" used to arrive at the estimated physically accessible surplus to current needs fibre supply.

${ }^{8}$ Backman 1996 shows share of the fiber supply with commercial significance by major specie group (coniferous, deciduous).
} 


\section{Manufacturing and Financial Health of the Sector}

It is not only the large surplus capacity in the forest relative to current utilization that has attracted interest, but there is a large unused capacity to manufacture forest products, growing since the demise of the FSU (Backman 1998a). This unused capacity is apparently standing ready to meet rising domestic demand, or increasing demand in European, Pacific Rim and other neighbouring regions, without requiring significant additional investment. However, much of this surplus capacity is left over from the former regime, ageing, of a generation of technology that was neither efficient nor necessarily environmentally friendly, with much constructed in an environment in which transportation costs were subsidized (Backman 1998b). A significant share of the unused capacity has emerged isolated by distance, relegated to a marginal role assuming an environment of higher prices, meeting domestic demand or demand in less quality-demanding markets.

With rising transportation tariffs and declining profitability, investment in newer technology has languished (Backman 1999). From a rather healthy profit in the early 1990s of more than 4 billion US \$, by 1997 the sector was losing about one billion US \$ (Goskomstat 1998b) seriously undermining its ability to meet obligations to the State, let alone modernize. In part, the poor state of the industry can be tied to a lag between declining output and complement of people in the sector. ${ }^{9}$ Given its poor financial state, the forest sector cannot be expected to generate the financial resources necessary to refurbish itself, let alone continue to contribute to public finances. Access to foreign markets is in jeopardy, at the very least from the viewpoint of quality. ${ }^{10}$

\section{Domestic Demand and Prices}

Up until the fall of the USSR, domestic consumption of major forest products rose steadily; though compared to western economies, Russian consumption still lagged far behind. Since the late 1980s, the fall in domestic consumption has been precipitous even as consumption in other developed countries such as Canada continued to rise (Backman 1995a). By 1997, consumption of such products as lumber and paper and paperboard were one sixth and one twentieth that of Canada, down from two thirds and one fifth as recent as 1989. Clearly, there is a large and growing opportunity to meet domestic demand which would amount to at least an additional 100 million cubic meters of harvest just in seeing a rise to one half the levels seen in Canada.

Although pent-up domestic demand is present, the ability of the population to support increased activity in the forest sector through consumption remains uncertain. Prices following the demise of the FSU were significantly lower than comparable prices in the markets of the Far Abroad. Lumber and particleboard were selling on the domestic market for one fifth the world level (Backman 1998) implicitly recognizing the differences in purchasing power of the population of the FSU, whose monthly income amounted to some 60 US \$ (Goskomstat 1998b). While incomes had risen to 160 US $\$$ by 1997 ,

\footnotetext{
${ }^{9}$ The forest sector output fell between 1990 and 1997 by 64 percent while employment levels declined by only $36 \%$ (Goskomstat 1998b).

${ }^{10}$ For further insight on quality differences and markets, see Waggener and Backman 1990.
}

comparable prices in the domestic market had also climbed to between $30 \%$ and $65 \%$ of the global levels. Placing prices relative to income in perspective, the monthly wages in Russia would purchase about one cubic meter of lumber. Comparable wages in Canada might purchase about 15 times that quantity. ${ }^{11}$

\section{Trade}

Under the former regime, the countries which had belonged to the FSU represented a significant share of trading activity accounting for more than $50 \%$ of the exports on a fibreequivalent basis (Backman 1995a). While manufactured products accounted for a significant share of the exports, roundwood still dominated, accounting for virtually all exports to China and Japan. The preponderance of unmanufactured roundwood in trade with virtually every major trading region underscores the tremendous opportunities available to substitute more deeply manufactured products for unprocessed wood. Furthermore, Russia in recent years has imported a significant quantity of paper products, reaching nearly one billion US \$ in 1997 before falling off slightly in 1998 (Goskomtam 1999). Indeed, given the large unused manufacturing capacity, one would think that such development could take place, although it is not without its challenges.

The trading pattern since the devolution of the former Soviet Union has changed dramatically. Exports to the former East European countries all but disappeared as economic activity declined and demand could be met from market economies (Backman 1998b). ${ }^{12}$ Exports to FSU countries other than Russia similarly collapsed, depriving the forest sector of what had been hitherto a market for about one half of the fibre exported under the former regime. These exports were often of a quality that would fail standards existing elsewhere. Increasing attention to quality and delivery criteria have contributed to an increase in exports in recent years, though they have failed to return to pre-breakup levels due to the absence of demand in the non-Russian countries of the FSU (Backman 1999).

Exports of more deeply manufactured products are concentrated in the European area though inroads continue to be made in Middle Eastern and Asian markets. The Central Asian republics and Kazakhstan constitute a large market for forest products of particular importance to the industry in Siberia. With the exception of Kazakhstan, they are devoid of forest resources and contain a large population and must rely almost completely on imported products. These markets and other parts of the FSU continue to stagnate, though, following the demise of the Soviet Union. Furthermore, future increases in non-FSU markets may be tempered should the Russian forest establishment fail to marshal the necessary resources to provide for proper stewardship of the forest resources even as quality and delivery concerns are addressed (Backman 1995b).

\footnotetext{
${ }^{11}$ The average annual income in 1997 was almost 40000 Can. \$ (Statistics Canada 1999a). Translating into US \$ ( 1 US $\$=1.38 .5$ Can. $\$$ ) amounts to about 28000 US \$ (Statistics Canada 1999b). A monthly income of some 2300 US $\$$ would buy about 15 times the quantity that a Russian monthly wage could $(2300 / 160 \approx 15)$,

${ }^{12}$ Waggener and Backman 1990 discuss the changing role of the former USSR as a purveyor of forest products to East European markets.
} 


\section{Financial Resources for Forest Management}

Since 1993, the Russian Federal Forest Service has been struggling to find resources necessary to support proper stewardship of the Russian forest resources. By 1996, resources were only one half that existing three years previously and were believed to be at least $25 \%$ less than the minimum necessary for the Forest Service to fulfil its duties (Backman 1998a, Shubin 1997). Not only does this undermine the ability of the forest service to fulfil its mandate to manage the forests, but it also undermines the credibility which the country as a whole must muster in order to convince consumers of the high level of stewardship of the resources supporting the manufacture of products destined for export. Failure to do so will place in jeopardy the employment supported by exports estimated to be at least one fifth to one quarter of the work force (Backman 1999).

While the resources made available to the Forest Service increased in 1997 to meet the minimum levels identified by Shubin (1997), even this level may be insufficient in the long term to guarantee market access. One estimate places financial resources needed at between 1.6 and 2.6 times the levels obtained in 1997. While the low estimate is slightly less than the contribution made to public coffers by the forest sector in 1997, the upper limit would exceed this level by at least 40\% (Backman 1999).

In 1997, the forest industry contributed over 6 billion rubles to public coffers (Vyskrebentsev and Yudin 1999). While this appears on paper to be sufficient to meet the lower boundary level, in reality the ability of the sector to meet its obligations to the public purse continues to deteriorate, placing in doubt its ability to meet government payments. Although the industry continues to allocate money to the federal budget, the indebtedness of the sector continues to grow, underscoring the need to take steps to re-structure itself in efforts to reduce costs, increase profitability, and generate positive cash flow. As of the end of 1997, the forest sector debt to the public sector was nearly equal to the amount of receipts claimed by government, significantly lower in European Russia and higher in Siberia and the Far East.

Recent developments in the carbon market may bode well for the cash-strapped Russian government. With output targets of carbon discharge linked to 1990 output, Russia has a significant quantity of "unused" carbon credits that could be traded on a short-term basis while the economy recovers. As a consequence of sharply lower economic activity, Russia has already seen its discharges reduced by $28 \%$ on 1990 levels, well in excess of the 6\% mandated by the Kyoto protocols (Duffy 1999). While difficult to estimate the value of such unused credits, the government could choose to allocate this financial stream to the Forest Service to help defray the costs of meeting the threshold stewardship levels, thus decreasing the risk that market access would be denied due to forest management issues.

\section{Discussion}

Since the collapse of the FSU, the forest industrial sector and forestry sector, as other components of the Russian economy, have seen output and prosperity plummet. Quantity of physical output in the forest sector between 1990 and 1997 fell while profitability of the sector deteriorated into losses by 1996 . Current output varies between $25 \%$ and $40 \%$ of the installed capacity, down considerably from levels experienced as recent as 1989. Since the demise, re-investment in the sector has fallen behind other sectors proportionally as well as absolutely on a year-to-year basis, underscoring the abyss into which the sector has fallen. Re-investment has fallen even though the cost of Russian-made capital goods is considerably less than the cost of similar goods in the West (Backman 1999). The age of the manufacturing capacity is of sufficient vintage to compromise the degree to which the export potential can be realized. With the collapse in domestic markets and markets in the former COMECON and FSU, enterprises in Russia have searched for new markets, with trade now accounting for a greater share of overall activity than it did in the FSU era (Backman 1999). Along with the declining fortunes of the industry, there was until 1997 a sharp fall in the financial resources made available to the Russian Federal Forest Service, which saw the real value fall by one half between 1993 and 1996.

While some sectors have begun the road to recovery since 1997, with the plywood sector, reconstituted panel sector and pulp sector seeing increases in output of almost 7 percent during 1998, harvest output and lumber production continued to fall by almost $10 \%$. The bright spots in the deeper manufacturing sectors are complemented by the growing importance of trade to sustain domestic output; export levels have generally held up since the early 1990s, even as domestic output plummeted. As opportunities and prospects in other Republics belonging to the former Soviet Union and former COMECON countries faded, markets were found elsewhere; though total export levels last seen in the pre-breakup days have yet to be reached.

The declines have been felt unevenly across the country. The declines are more pronounced in West Siberia and the Far East than in East Siberia and European Russia due to the existence of secondary manufacturing facilities in East Siberia that can produce products supporting the sharply higher transportation tariffs and the large domestic market and proximity to foreign markets in European Russia. A manufacturing capacity installed during a regime in which transportation costs were subsidized, a collapse of both domestic regional markets and demand in traditional markets of Republics belonging to the FSU, an inability to attract investment in requisite amounts, and growing concerns linked to stewardship issues over the forest are challenging the forest sector of Russia.

Clearly, the future outlook for the forest sector of East and West Siberia is linked to markets in the east in countries of the Pacific Rim, to the south and west in countries belonging to the FSU, regions of European Russia and in the rest of Europe. The distance to markets in the west and east favours deeper manufacture of forest products that can successfully support the transportation tariffs, while markets in the south must await recovery in the economic fortunes of the non-Russian FSU countries. Exporting more deeply manufactured products in order to preserve employment opportunities will require creating a positive investment climate that respects property rights and creating the impression of proper stewardship of the forest resources to ensure market access.

Recognizing the potential of the forest sector to contribute to rising prosperity of the Russian peoples and nation, the government has introduced a program for the reconstruction of the forest industrial complex of Russia designed to significantly alter the landscape of the sector by the year 2005. Key to the expectations of the forest sector are increasing domestic consumption of paper products and attracting investment. Exports 
of paper products are expected to increase, though this in large measure must wait for significant investment in equipment while there will be increasing substitution of exported roundwood with more deeply manufactured products. The domestic market is expected to increase, driven by the increase in demand in the construction sector of the economy; though the ability of the population to support construction out of personal resources needs to be examined, including the impact which higher interest rates has on the disposable income of the population.

The need for large financial resources and the poor shape of the sector will be addressed through creation of large vertical companies, which by the end of the planning period are expected to account for $65 \%$ of output, up significantly from $30 \%$ in the current planning period (Levina 1998). In the process of creating holding companies, the overall cost structure is expected to decrease by $20 \%$, increasing attractiveness to foreign investors; though Russia is still troubled by a poor image in the West. ${ }^{13}$ Furthermore, encouraging concentration of output in fewer organizations raises questions over the ownership structure, the degree of autonomy granted existing management, and the extent to which providers of capital can protect their investment. The mixed ownership structure of the sector, over-staffing, and chronic problems experienced by purchasers of Russian assets suggest that attracting capital without addressing larger questions may prove troublesome given the current state of the sector and its past performance.

With the importance of foreign markets indisputable, the sharp drop in Russia Forest Service funding is troublesome not only from a market access viewpoint but also from a wider arena given Russia's global responsibilities for stewardship of one half of the World's coniferous resource and two thirds of its boreal forest. The perils associated with dependency on the budget allocation process at a time of financial crisis cannot be overstated. Since forestry may not rank very high on the priorities for the budgetary process, forestry faces a risk of being chronically under-funded unless more of the revenue stream currently and potentially flowing from the sector can be tied directly to forestry expenditures. Forestry with its long-term horizon may be unable to effectively compete for the extra funds believed necessary with short-term travails constantly rearing their collective heads. While some see the sale of carbon credits as a means to generate additional cash flow for the public sector, caution is in order. Purchasing credits linked to a decline in production assumes that the disposing agency in Russia has the ability to prevent the re-emergence of a domestic industry relying on older Soviet-era technology during the time frame in which the offsets would be valid.

\section{Policy Implications}

The future outlook for the Russian forest sector thus remains clouded for a number of reasons, including the following: (1) an ageing manufacturing capacity; (2) a poor

\footnotetext{
${ }^{13}$ Russia continues to suffer from a poor investment climate ranking lowest of 59 countries in a survey by the World Economic Forum (Richards 1999). Nearly 4000 business executives were polled on how countries were viewed in terms of eight criteria. The criteria were (1) openness; (2) government; (3) finance; (4) infrastructure; (5) technology; (6) management; (7) labor; (8) institutions. Ukraine and Russia were ranked at the bottom of list due to organized crime, unreliable property rights, poor infrastructure and low trust in government.
}

investment climate complicated by poorly defined property rights; (3) an uneconomic industrial structure; (4) an inability to contribute significantly to government coffers; (5) an over-staffing relative to current output; (6) an undeveloped market in the nonRussian countries belonging to the FSU; (7) pent-up domestic demand coupled with limited purchasing power of the population; (8) and foreign market access linked to quality and stewardship issues.

These reasons are not independent of each other as solutions for one provide the answer to others. With the need to attract capital, creating an investment climate which favours a lower interest rate environment is key. Without the capital to invest in roads, new harvesting and manufacturing technologies, the fibre supply will fail to reach economic levels, the forest sector will continue to stagger, burdened by over-staffing and an inefficient organization structure, quality of products will not impress buyers having choices, and more importantly, lack of finances for forest management will place at risk the market access on which even now so much depends. Without successful restructuring, profitability will be challenged, affecting the ability to attract investment and contribute to the funding of forest management. Construction of deeper manufacturing capacity to overcome the tyranny of distance will be placed in doubt.

In order to address these problems, the Russian government should focus on tasks which promote more secure property rights and a confidence in the longer-term horizon. Some consideration should be given to transfer of ownership of resources and responsibility for resources to a more local level of government. Absentee landlords in a culture that does not respect property rights only encourage abuse. To encourage modernization of the manufacturing base, all levels of government should think in terms of accelerated depreciation of invested capital while every effort should be made to make use of and promote the purchase of domestically manufactured equipment. If the domestic designs are inappropriate, joint ventures with foreign firms manufacturing under license could take advantage of the lower cost structures that currently exist in Russia. Firms should be allowed to go into bankruptcy; and in the process of emerging, be permitted to shed workers. Contributions to public coffers will increase with a successful restructuring though there needs to be increasing effort on the part of the tax authorities to identify in a timely manner firms which are not contributing their share to the public purse. Organizations that are chronically in arrears could be encouraged to perform needed forest management work on their forest concessions in exchange for outstanding debt or in exchange for current taxes owed. A domestic market in forest products could be encouraged through creation of a central agency to lend financial resources to people wishing to acquire their own domicile. Foreign market access will be addressed through modernization of the manufacturing base (addressing quality issues) while the stewardship question will be addressed through increased payments to public authorities on the basis of a restructured industry, better collections from the industry, and/or increasing forest management work on the part of local users in exchange for taxes owed.

\section{Acknowledgements}

The author would like to thank Dr. Gail Fondahl of UNBC for insightful comments made during the seminar and to Dr. 
Winifred Kessler of UNBC for extending the invitation to come and present at UNBC.

\section{References}

Backman, C.A. 1995a. The Russian forest sector: An analysis by four regions, WP-95-44. International Institute for Applied Systems Analysis (IIASA). Laxenburg, Austria. 160 p.

Backman, C.A. 1995b. The Russian forest sector - Production, consumption, and export prospects. Post Soviet Geography 36(5): 310-322.

Backman, C.A. 1996. The Russian forest sector: Prospects for trade with the former Soviet republics. Post Soviet Geography and Economics 37(1): 16-59.

Backman, C.A. 1998a. Russia. In Forest policy: International case studies. pp. 233-253. CABI Publishing, Wallingford, UK.

Backman, C.A. 1998b. The forest industrial sector of Russia: Opportunity awaiting. Parthenon Publishing Group, Carnforth, UK. 297 p.

Backman, C.A. 1999. The Siberian forest sector: Challenges and prospects. Post Soviet Geography and Economics 40(6): 453-469. Duffy, A. 1999. Kyoto will cost Canada dearly: study. Financial Post, Monday, October 25. p. C3.

Goskomstat. 1998a. Promyshlennost' rossii 1998 (Industry of Russia 1998). Goskomstat rossii, Moscow, Russia. 444 p.

Goskomstat. 1998b. Rossiyskiy statisticheskiy ezhegodnik 1998 (Russian statistical yearbook 1998). Goskomstat, Moscow, Russia. 813 p.
Goskomtam 1999. Tamozhennaya statistika vneshney torgovli rossiyskoy federatsii - 1998 (Custom data for the external trade of Russia - 1998). Goskomtam, Moscow, Russia.

Levina, L.I. 1998. Programma restrukturizatsii lesopromyshlennogo kompleksa Rossii (Program for reconstruction of the forest industrial complex). Lesnaya Promyshlennost' (Forest Industry). No. 4, oktyabr'-dekabr' (October-December): 2-5.

Richards, S. 1999. Singapore is still most competitive economy: Russia is on bottom in global survey. Wall Street Journal. July 14, p. A18. Statistics Canada. 1999a. Employment, earnings and hours, Catalogue no. 72-002-XPB, Vol. 77, no. 07. Statistics Canada, Ottawa, Canada.

Statistics Canada. 1999b. Canadian economic observer, Catalogue no. 11-010-XPB, May 1999, Statistics Canada, Ottawa, Canada.

Shubin, V.A. 1997. Zadachi lesovodov Rossii v novom godu (Challenges of forest management in the new year). Lesnoe Khozyaystvo (Forest Economy) No. 1: 2-5

Vyskrebentsev, I.K. and E.A. Yudin. 1999. Analiz sovremennogo sostoyaniya lesnogo kompleksa I dinamiki postupleniya nalogovykh platezhey (Analysis of the current conditions of the forest complex and the dynamics of the receipt of tax payments). Lesnoe Khozyaystvo (Forest Economy) No. 1: 28-31.

Waggener, T.R. and C.A. Backman. 1990. Eastern Europe trade in forest products: Changing role of the USSR and opportunities for the US forest products industry. Report prepared for the National Forest Products Association, October 1990. Washington, USA. 293 p. 